International Journal of Agricultural and Applied Sciences, June 2021, 2(1):61-67

https://www.agetds.com/ijaas

ISSN: 2582-8053

https://doi.org/10.52804/ijaas2021.217

Research Article

OPEN ACCESS

\title{
Effect of number of seedlings per hill on performance and yield of spring rice (Oryza sativa L.) in Rajapur, Bardiya, Nepal
}

\author{
Hikmat Paudel $^{* 1}$, Suman Dhakal ${ }^{1}$, Kalyani Shrestha ${ }^{1}$, Hemanta Paudel ${ }^{2}$ and Dikshya Khatiwada ${ }^{1}$ \\ ${ }^{1}$ Agriculture and Forestry University, Chitwan, Nepal \\ ${ }^{2}$ Institute of Agriculture and Animal Science, Tribhuwan University, Nepal \\ Corresponding author e-mail: hikmatpaudel96@gmail.com
}

(Received: 18/01/2021; Revised: 14/04/2021; Accepted: 19/06/2021)

\begin{abstract}
It is assumed that the rice grain yields can be increased by using the optimum number of seedlings per hill during transplant. In order to know the effect of the number of seedlings hill ${ }^{-1}$ on the performance and yield of spring rice, a field experiment was conducted from February to June 2020 at Rajapur municipality, Bardiya, Nepal. The experiment was conducted in Randomized Complete Block Design (RCBD) comprising five treatments viz., one, two, three, four, and five seedlings hill ${ }^{-1}$ with four replications. Hardinath ${ }^{-1}$ variety of rice was used at a spacing of $20 \mathrm{~cm} * 20 \mathrm{~cm}$, with an individual plot size of $3 \mathrm{~m} * 2 \mathrm{~m}$. Data for growth parameters, yield attributes, and yield were collected. All the data was entered and tabulated using MS-Excel while Analysis of variation and mean separation was done using R-Studio. The effect of number of seedlings hill ${ }^{-1}$ on yield and most of the yield attributing characters was found to be significant. Two seedlings hill ${ }^{-1}$ had the greatest plant height $(94.78 \mathrm{~cm})$, highest tiller per meter square (358.75), effective tiller per meter square (303.75), panicle length $(24.27 \mathrm{~cm})$, and the number of filled grains per panicle (120.43). Grain yield and straw yield (6.57 t/ha and $10.18 \mathrm{t} / \mathrm{ha}$ ) were also highest at two seedlings per hill. Economic parameters like production cost, gross return, the net return, and B:C ratio varied significantly with the number of seedlings hill ${ }^{-1}$. The highest production cost $\left(74.36\right.$ thousand NRs. ha $\left.{ }^{-1}\right)$ incurred at five seedlings hill ${ }^{-1}$ and gross return (177.39 thousand NRs. ha $\left.{ }^{-1}\right)$, net return (105.67 thousand NRs. ha ${ }^{-1}$ ), and B:C ratio (2.47) was highest at two seedlings hill-1.
\end{abstract}

Keywords: Rice, yield, seedlings, spring.

\section{INTRODUCTION}

The agrarian sector in Nepal is dominated by cereal crops, primarily, rice, maize, and wheat. Rice (Oryza sativa L.) is the most important staple food of more than half of the world's population (Muthayya, Sugimoto, Montgomery, and Maberly, 2014). Rice occupies first place in terms of area coverage, production, productivity, and preferences in Nepal and it contributes $15.35 \%$ to the AGDP, with average productivity of $3.76 \mathrm{mt} / \mathrm{ha}$, in the fiscal year 2075/76 B.S. (MoALD, 2020). Rice is cultivated for three seasons in Nepal, main season rice (barkhedhan), boro rice or winter season rice, and spring season rice (chaitedhan). Main season rice has broader coverage as compared to other rice because of the availability of rainfall, however, the productivity of the crop is higher in the spring season. Recent data reveals the productivity of spring rice is $4.50 \mathrm{mt} / \mathrm{ha}$ while that of main season rice is $3.70 \mathrm{mt} / \mathrm{ha}$. (MoALD, 2020). Nevertheless, the productivity of rice in Nepal is 3.76 ton/ha, which is lower than the world average productivity of 4.67 ton/ha (FAOSTAT, 2019). This highlights the immense potential to increase rice productivity and total production in Nepal.

Nepal used to export rice in the past, now imports about one million ton of milled rice every year (Tripathi, Bhandari, and Ladha, 2019). Nepal imported 473,715 tons of rice (milled only) worth 229 million US\$ in the year 2018 (FAOSTAT, 2019). Different future projections show a persistent shortfall in the domestic production of rice in Nepal to meet the total demand. Despite higher productivity compared to main season rice, spring rice cultivation is limited to a small area in Nepal. Rajapur municipality and Geruwa rural municipality of Bardiya district are designated as rice superzone under PMAMP. In the district, rice is grown over 49,236 ha area with a total production of 212,207 metric tons and a yield of $4.31 \mathrm{mt} / \mathrm{ha}$ (PMAMP, 2019). Rice growers of the study area are unwary of the appropriate seedling density hill ${ }^{-1}$ for optimum yield in the region. So, the huge gap between demand and domestic production can be minimized through extensive cultivation of spring rice with proper agronomic management practice of farming. Excessive 
no. of seedlings hill-1 results in a higher tiller population but it increases the interplant competition and leads to mutual shading, lodging, and production of more straw instead of grain. On the other hand, a lower number of seedlings hill $^{-1}$ may produce insufficient tiller, keeping space and nutrients unutilized resulting in lower no. of panicles per unit area and ultimately the poor yield (Miah, Talukder, Sarkar, and Ansari, 2004). Optimum seedlings hill- $^{-1}$ facilitates proper growth of both the aerial and underground parts of the crop by proper utilization of solar energy, nutrients, space, and moisture. Also, this reduces seedling costs to the farmers (Azad, 2004). Seedling density hill ${ }^{-1}$ is an important factor affecting tiller population per unit area which ultimately influences the yield (Bhowmik, Sarkar, and Zaman, 2012). Generally, if a single seedling is used per hill, then there are chances of wasting some hills, however, if more than optimum seedlings hill-1 is used then there will be overuse of seedlings (Barua, Islam, Zahan, Paul, and Shamsunnaher, 2014). If fewer seedling hill ${ }^{-1}$ is used, the probable yield cannot be realized and if extra seedlings are used it might not be cost-effective (Gurjar, Swami, and Meena, 2018).

Previous researches have been conducted to study the rate of seedlings mainly focusing on rainy season rice. Since the ecology and growing environment of spring season rice is completely different, a trial for evaluating the number of seedlings per hill in the case of spring rice is quite essential. Therefore, the study was undertaken to evaluate the effect of different seedling density hill ${ }^{-1}$ on performance and yield, and the economics of spring rice.

\section{MATERIALS AND METHODS}

\section{Site Selection}

The experiment was conducted in a farmer's field at ward No. 07, Bhimapur of Rajapur municipality (latitude: $28^{\circ} 17^{\prime}$, longitude $81^{\circ} 41^{\prime}$ ), which is the command area of Rice Superzone, Bardiya. The site lies in the tropical region of Nepal, characterized by three distinct seasons and they are hot spring (March-May), rainy (June-October), and cool winter (NovemberFebruary). The research was conducted during spring and weather parameters were collected from weather world online.

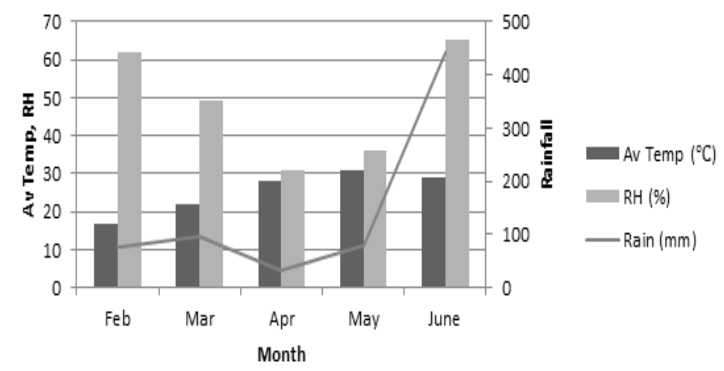

Figure 1: Diagram showing monthly mean temp, RH, and rainfall of Bardiya during the research period (month), 2020 Source: worldweatheronline.com

\section{Experimental details}

Fungicide application was done to pre-sorted seeds and the seedlings were raised on plastic trays after pregermination on jute sack. Hardinath ${ }^{-1}$ variety of rice was used in the experiment that was laid out in Randomized Complete Block Design (RCBD) with five treatments and four replications. The treatments comprised five seedling densities viz. one, two, three, four, and five per hill, each transplanted on an area of $3 \mathrm{~m} \times 2 \mathrm{~m}$ in the main field. The spacing between the plots and replications was $1 \mathrm{~m}$ each. The recommended dose of nutrient (100:30:30 Kg NPK ha-1) was applied, one-third of nitrogen and a full dose of phosphorus and potash was applied as basal dose, while the remaining two-third dose of nitrogen was applied at tillering stage and panicle initiation stage in equal splits. A spacing of $20 \mathrm{~cm} \times 20 \mathrm{~cm}$ was used between seedlings as illustrated in Fig. 2

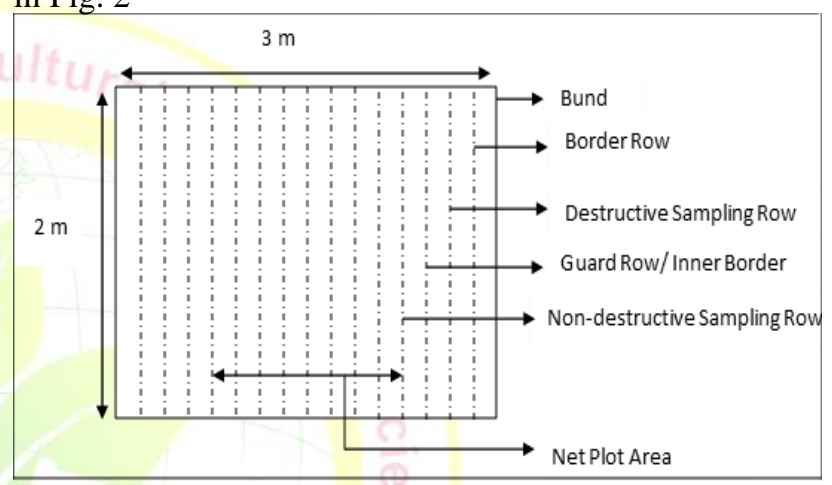

Figure 2: Layout of an individual plot in Bardiya, Nepal, 2020

The observations were recorded from ten randomly selected plants measured from the non-destructive sampling rows ( $4^{\text {th }}$ row) at an interval of 15 days starting from 30 DAT to 90 DAT. The parameters include plant height, number of tillers per meter square, effective tillers per meter, length of panicle, total unfilled grains per panicle, sterility percentage, thousand-grain weight, grain yield, straw yield, and Harvest Index.

\section{Economic analysis}

Economic analysis was done based on local charges. The production cost, gross return, net return, and $\mathrm{B}: \mathrm{C}$ ratio was calculated. All the observed data were properly arranged using MS excel and analysis of variance at a 5\% level of significance was done using R-studio software. Word processing was done through MS word.

\section{RESULTS AND DISCUSSION}

The results obtained during the experiment are analyzed and presented in this section with the help of the tables and figures wherever necessary. The results obtained are discussed with possible reasons and literature support.

\section{Biometric observations \\ Plant Height}

The study revealed that the average plant height varied significantly during the observations at an interval of 15 
days, after 45 DAT (Table 1). The average height varied from $54.98 \mathrm{~cm}$ at 45 DAT to $91.14 \mathrm{~cm}$ at 90 DAT. The plant height at 30 DAT was not significantly influenced by the number of seedlings hill-1 ${ }^{-1}$ At 45, 60, 75 , and 90 DAT, the highest plant height was obtained from two seedlings hill-1 which was statistically similar with one seedling hill-1, followed by three seedlings hill-1 ${ }^{-1}$ Lower plant heights were obtained at five seedlings hill ${ }^{-1}$ during all the observations. By 90 DAT, the highest plant height obtained for two seedlings hill ${ }^{-1}$ which was $94.78 \mathrm{~cm}$ while it was lowest for five seedlings hill-1 which was $87.99 \mathrm{~cm}$.

The results are in alignment with the results obtained by Alam et al. (2012), who reported the highest plant height on transplanting two seedlings hill-1 and lowest with five seedlings hill $^{-1}$, statistically identical to four seedlings hill ${ }^{-1}$. Similarly, Bhowmik et al. (2012) previously reported the tallest plant at two seedlings hill $^{-1}$ and shortest at five seedlings hill-1 . The decrease in plant height with an increased number of seedlings hill $^{-1}$ was due to the competition between the plants for space, light, and nutrients (Islam et al., 2008).

Table 1. Plant height and number of tillers per meter square of spring rice at different DAT as influenced by the number of seedlings hill ${ }^{-1}$ in Bardiya, Nepal, 2020

\begin{tabular}{|c|c|c|c|c|c|c|c|c|}
\hline \multirow[b]{2}{*}{ Treatments } & \multicolumn{3}{|c|}{ Plant Height $(\mathrm{cm})$ at DAT } & \multirow[b]{2}{*}{90} & \multicolumn{4}{|c|}{ Number of tillers per meter square at DAT } \\
\hline & 45 & 60 & 75 & & 45 & 60 & 75 & 90 \\
\hline One seedling hill ${ }^{-1}$ & $56.01^{\mathrm{a}}$ & $64.25^{\mathrm{a}}$ & $89.72^{b}$ & $93.03^{\mathrm{a}}$ & $324.38^{\mathrm{b}}$ & $410.00^{\mathrm{b}}$ & $306.25^{\mathrm{c}}$ & $265.00^{\mathrm{c}}$ \\
\hline Two seedlings hill-1 & $57.18^{\mathrm{a}}$ & $64.80^{\mathrm{a}}$ & $92.56^{\mathrm{a}}$ & $94.78^{\mathrm{a}}$ & $408.75^{\mathrm{a}}$ & $500.00^{\mathrm{a}}$ & $392.50^{\mathrm{a}}$ & $358.75^{\mathrm{a}}$ \\
\hline Three seedlings hill ${ }^{-1}$ & $55.36^{\mathrm{a}}$ & $63.43^{\mathrm{ab}}$ & $87.34^{\mathrm{c}}$ & $91.09^{b}$ & $358.13^{\mathrm{b}}$ & $412.50^{\mathrm{b}}$ & $333.75^{\mathrm{bc}}$ & $298.75 b^{b c}$ \\
\hline Four seedlings hill ${ }^{-1}$ & $54.65^{\mathrm{ab}}$ & $61.84^{\mathrm{b}}$ & $85.53^{\mathrm{d}}$ & $88.81^{\mathrm{c}}$ & $365.00^{\mathrm{b}}$ & $431.25^{\mathrm{b}}$ & $338.75^{\mathrm{bc}}$ & $291.25^{\mathrm{bc}}$ \\
\hline Five seedlings hill-1 & $51.72^{\mathrm{b}}$ & $59.63^{c}$ & $84.59^{d}$ & $87.99^{c}$ & $416.25^{\mathrm{a}}$ & $515.63^{\mathrm{a}}$ & $363.75^{\mathrm{ab}}$ & $313.75^{b}$ \\
\hline $\operatorname{SEM}( \pm)$ & 0.63 & 0.51 & 0.70 & 0.65 & 11.37 & 9.51 & 8.39 & 8.52 \\
\hline LSD (0.05) & 3.38 & 2.00 & 1.49 & 1.90 & 40.92 & 40.41 & 42.66 & 37.90 \\
\hline F-test & $*$ & $* *$ & $* *$ & $* *$ & $* *$ & $* *$ & $* *$ & $* *$ \\
\hline $\mathrm{CV}(\%)$ & 4.00 & 2.07 & 1.10 & 1.35 & 7.09 & 5.78 & 7.98 & 8.05 \\
\hline Grand Mean & 54.98 & 62.79 & 87.95 & 91.14 & 374.5 & 453.88 & 347 & 305.5 \\
\hline
\end{tabular}

Note: DAT, days after transplantation; NS, non-significant; LSD: least significant differences, SEM ( \pm ): Standard error of the mean, CV: Coefficient of variation, Treatment means separated by Duncan's Multiple Range Test and columns represented with the same letter(s) are not significantly different among each other at 5\% level of significance.

\section{Effective tillers $\mathbf{~ m}^{-2}$}

Table 2 shows that the effective tillers $\mathrm{m}^{-2}$ was found to be significantly different for different number of seedlings hill $^{-1}$. The highest number of effective tillers $\mathrm{m}^{-2}$ (303.75) was found at two seedlings hill ${ }^{-1}$ followed by three seedlings hill $^{-1}$ (263.13), and a higher number of seedlings hill ${ }^{-1}$ resulted in lower effective tillers. This result is in close conformity with Masum et al. (2014) and Ehsanullah et al. (2012) who also reported the highest effective tillers with two seedlings hill ${ }^{-1}$ and lowest with four seedlings hill'-1. Also, Ashraf et al. (1999) mentioned that the transplanting of 2 and 3 seedlings per hill gave a promising number of productive tillers per unit area. Transplanting more seedlings hill ${ }^{-1}$ results in more ineffective tillers production and did not contribute to the yield (Hasanuzzaman et al. 2009). The correlation

\section{Number of tillers per meter square}

Table 1 reveals that the number of tillers per meter square was significantly influenced by number of seedlings hill'-1 for each of the observations. The number of tillers per meter square increased progressively from 45 DAT (374.5) to 60 DAT (453.88) and decreased thereafter till 90 DAT (305.5). Initially, five seedlings hill ${ }^{-1}$ produced higher tillers until 60 DAT. After the maximum tillering stage, two seedlings hill ${ }^{-1}$ exceed five seedlings hill ${ }^{-1}$ and produced higher tillers per meter square which might be due to more intra-competition in the case of five seedlings hill ${ }^{1}$. At 45 DAT and 60 DAT, the highest number of tillers per meter square was for five seedlings hill ${ }^{-1}$ which was statistically similar to two seedlings hill'-1 whereas it was least for one seedling per hill which was statistically similar to three and four seedlings hill ${ }^{-1}$. Similarly, at 75 DAT and 90 DAT, two seedlings hill ${ }^{-1}$ produced the highest tillers per meter square (392.50 and 358.75) whereas one seedling hill${ }^{1}$ produced the lowest tillers per meter square (306.25 and 265.00). 
correlation $\left(\mathrm{r} \quad=0.485^{*}\right) \quad$ between panicle length and grain yield with a coefficient of determination reflecting $23.4 \%$ contribution to the total grain yield due to panicle length and rest was governed by other factors, as depicted in Figure 4. Previously, Lakshmi et al. (2014) had registered a positive and significant relation between panicle length and grain yield per plant.

\section{Filled grains panicle ${ }^{-1}$}

The highest number of filled grains per panicle was obtained for two seedlings hill ${ }^{-1}(120.43)$ and three seedlings hill-1 (118.70) (Table 2). The highest number of grains per panicle in case of two seedlings hill ${ }^{-}$ ${ }^{1}$ might be due to the longest length of the panicle. Faruk, Rahman, and Hasan (2009) also reported similar results with the highest number of filled grains per panicle at two seedlings hill- ${ }^{-1}$. Inaba and Kitano (2005) also reported that the number of grains per panicle decreased with increased seedling density. A coefficient of determination of 0.480 was observed with a positive correlation $\left(\mathrm{r}=0.693^{* *}\right)$ between filled grains per panicle and grain yield (Figure 5).

Table 2. Yield attributes of spring rice as influenced by number of seedlings hill-1 in Bardiya, Nepal, 2020

\begin{tabular}{|c|c|c|c|c|c|}
\hline Treatments & Effective tillers $\mathrm{m}^{-2}$ & Panicle length $(\mathrm{cm})$ & Filled grains panicle ${ }^{-1}$ & Sterility \% & TGW \\
\hline One seedling hill- ${ }^{-1}$ & $241.88^{\mathrm{bc}}$ & $23.96^{\mathrm{a}}$ & $113.33^{\mathrm{b}}$ & 24.10 & 21.83 \\
\hline Two seedlings hill- ${ }^{-1}$ & $303.75^{\mathrm{a}}$ & $24.27^{\mathrm{a}}$ & $120.43^{\mathrm{a}}$ & 24.98 & 20.67 \\
\hline Three seedlings hill- & $263.13^{\mathrm{b}}$ & $23.89^{\mathrm{a}}$ & $118.70^{\mathrm{ab}}$ & 26.54 & 20.38 \\
\hline Four seedlings hill ${ }^{-1}$ & $222.50^{\mathrm{c}}$ & $22.89^{b}$ & $104.80^{c}$ & 28.50 & 22.93 \\
\hline Five seedlings hill- ${ }^{-1}$ & $238.13^{\mathrm{c}}$ & $22.91^{\mathrm{b}}$ & $112.90^{\mathrm{b}}$ & 27.65 & 21.17 \\
\hline $\operatorname{SEM}( \pm)$ & 7.107 & 0.170 & 1.474 & 0.570 & 0.448 \\
\hline $\operatorname{LSD}(0.05)$ & 23.92 & 0.85 & 5.85 & NS & NS \\
\hline F-test & $* *$ & $*$ & $* *$ & & \\
\hline $\mathrm{CV}(\%)$ & 6.11 & 2.35 & 3.33 & 8.35 & 10.31 \\
\hline Grand Mean & 253.88 & 23.58 & 114.03 & 26.35 & 21.40 \\
\hline
\end{tabular}

Note: TGW: thousand-grain weight, NS, non-significant; LSD: least significant differences, SEM $( \pm)$ : Standard error of the mean, CV: Coefficient of variation, Treatment means separated by Duncan's Multiple Range Test and columns represented with same letter(s) are not significantly different among each other at 5\% level of significance.

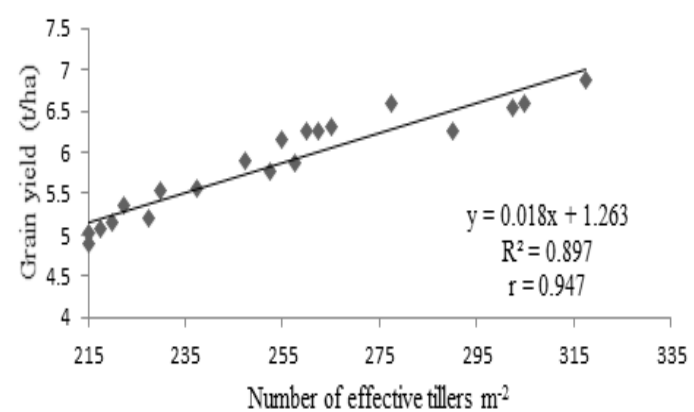

Figure 3. Relationship between effective tillers $\mathrm{m}^{-2}$ and grain yield as influenced by number of seedlings hill ${ }^{-}$ ${ }^{1}$ at Rajapur, Bardiya, 2020

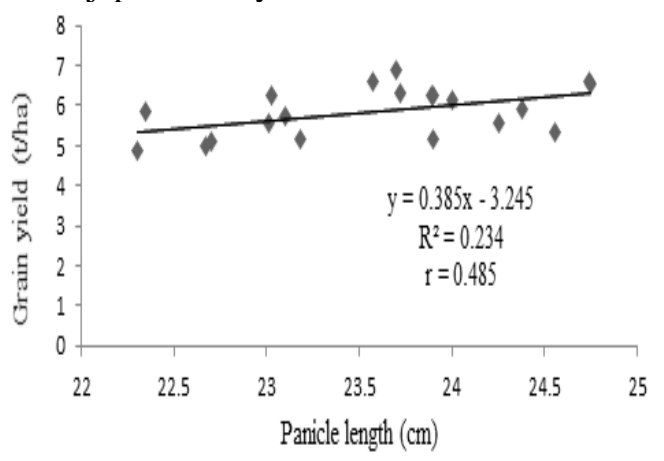

Figure 4. Relationship between panicle length and grain yield as influenced by number of seedlings hill ${ }^{-}$ ${ }^{1}$ at Rajapur, Bardiya, 2020

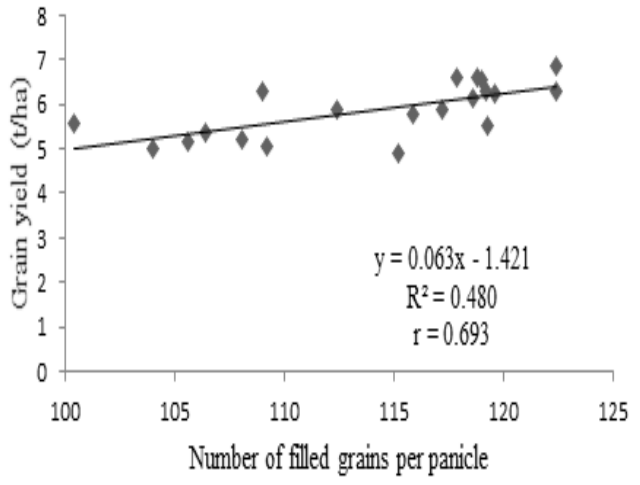

Figure 5. Relationship between filled grains per panicle and grain yield as influenced by number of seedlings hill ${ }^{-1}$ at Rajapur, Bardiya, 2020

\section{Sterility $\%$ and Thousand-grain weight}

Based on the analysis, the sterility percentage andan average weight of thousand grains were found to be non-significant forthe different number of seedlings hill $^{-1}$. The results are similar to those reported by Rasool et al. (2012) and Ashraf et al. (1999). Thousandgrain weight was not significantly affected by the number of seedlings hill-1 (Rahman et al., 2007). Grain weight was not influenced significantly due to different treatments because it is stable varietal character and the grain size is rigidly controlled by the hull (Yadanar et al., 2018). 


\section{Grain yield, straw yield, and harvest index Grain yield}

The diagram in figure 6 shows that the effect of different numbers of seedlings hill ${ }^{-1}$ was highly significant for grain yield and straw yield. The mean grain yield of the experiment was observed to be 5.86 $\mathrm{t} / \mathrm{ha}$ in the experiment. The highest yield (6.57 t/ha) was observed at two seedlings hill ${ }^{-1}$. Lower grain yields were observed at four seedlings hill $^{-1}$ and five seedlings hill' ${ }^{-1}$. The highest yield in two seedlings hill ${ }^{-}$ ${ }^{1}$ could be due to a higher number of productive tillers and more interception of light. Higher seedling densities recorded low grain yield which was lowest at four seedlings hill-1 due to less effective tillers $\mathrm{m}^{-2}$ and fewer assimilation rates at higher seedling numbers (Rasool et al., 2012). So, planting fewer seedlings is considered optimum for higher grain yield. Faruk et al. (2009), Sarkar et al. (2011), and Masum et al. (2014) also reported results in accord with the above results. Grain yield had a positiveand significant association with the number of effective tillers per plant, plant height, and kernel length suggestingsuch traits as a criterion for yield improvement (Lakshmi et al., 2014).

\section{Straw yield and Harvest index}

The mean straw yield observed was $9.01 \mathrm{t} / \mathrm{ha}$. The highest straw yield (10.18 t/ha) was recorded at two seedlings hill ${ }^{-1}$ at par with three seedlings hill ${ }^{-1}(9.25$ $\mathrm{t} / \mathrm{h})$. Similarly, the lowest straw yield (8.33 t/ha) was recorded at four seedlings hill ${ }^{-1}$ at par with five seedlings hill ${ }^{-1}(8.88 \mathrm{t} / \mathrm{ha})$ and one seedling hill-1 ${ }^{-1}(8.40$ $\mathrm{t} / \mathrm{ha}$ ). The higher number of total tillers could be responsible for higher straw yield in two seedlings hill ${ }^{-}$ 1. Ashraf et al. (1999) also recorded higher straw yield at two seedlings hill-1. Higher straw yield can be attributed to the higher number of total tillers per meter square (Rahman et. al., 2007; Bhowmik et. al., 2012).

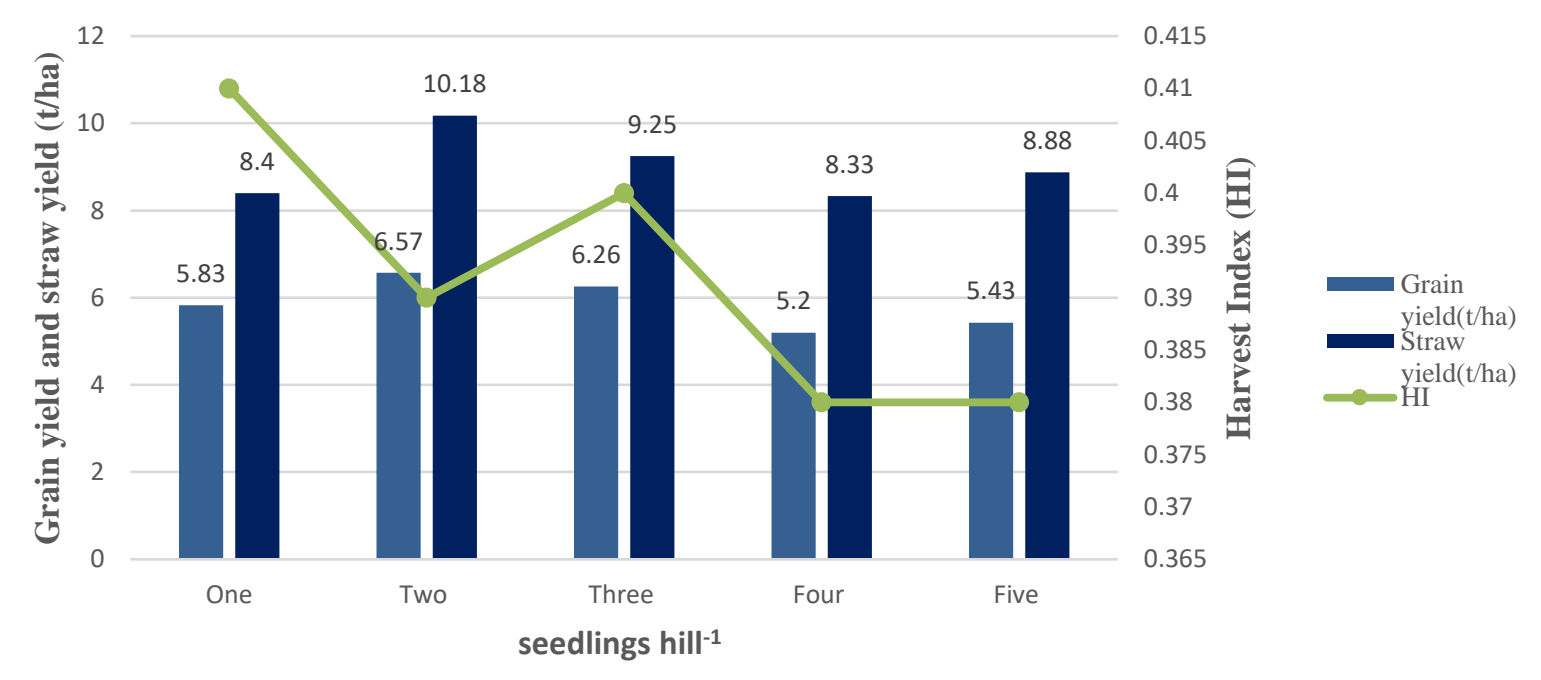

Figure 6. Grain yield, straw yield, and harvest index of spring rice as influenced by the number of seedlings hill ${ }^{-1}$ in Bardiya, Nepal, 2020

No significant effect of the number of seedlings per hill was observed in the case of the Harvest Index. Dejen (2018) also reported non-significant differences in harvesting index to the number of seedlings hill ${ }^{-1}$.

\section{Economic analysis}

The average cost of production, gross and net returns, and $\mathrm{B}: \mathrm{C}$ ratio of spring rice attributed to different seedling hill ${ }^{-1}$ is shown in Table 3 . The average cost of cultivation was the highest cost for five seedling hill-1 (NRs. 65.25 thousand $\mathrm{ha}^{-1}$ ) and highest in one seedling hill $^{-1}$ (NRs. 61.73 thousand ha $^{-1}$ ). Significantly higher gross return was obtained in two seedlings hill ${ }^{-1}$ (N Rs. 177.39 thousand $\mathrm{ha}^{-1}$ ) attributed to its higher grain yield, followed by three seedlings hill $^{-1}$ (NRs. 169.02 thousand $\mathrm{ha}^{-1}$ ). Similarly, net return varied significantly with the number of seedlings hill-1, where a higher net return was obtained in two seedlings hill ${ }^{-}$ ${ }^{1}$ (134.49 thousand NRs ha-1 ${ }^{-1}$. Whereas, lower net return was obtained in four and five seedlings hill-1
Significant differences among the number of seedlings hill $^{-1}$ was observed in the $\mathrm{B}: \mathrm{C}$ ratio with a mean $\mathrm{B}: \mathrm{C}$ ratio of 1.77 . The highest $B: C$ ratio was obtained in two seedlings hill-1 $^{-1}(2.15)$ which was due to reduced production cost and increased yield of the crop which ultimately increased gross and net return, whereas the least $\mathrm{B}: \mathrm{C}$ ratio was observed in four seedlings hill ${ }^{-1}$.

\section{CONCLUSION}

The study confirms the role of seedlings hill ${ }^{-1}$ in increasing the yield and a majority of yield attributes of rice as observed in the variety Hardinath ${ }^{-1}$. The observations reveal that a higher grain yield $(6.57 \mathrm{t} / \mathrm{ha})$ was observed at two seedlings hill-1 followed by three seedlings hill ${ }^{-1}$ (6.26 t/ha). Thus, two seedling hill ${ }^{-1}$ may be recommended for increasing rice yield particularly under tropical conditions such as Rajapur, Bardiya. Also, based on higher gross, net return, and $\mathrm{B}: \mathrm{C}$ ratio, two seedlings hill ${ }^{-1}$ gave maximum benefit in spring rice variety Hardinath ${ }^{-1}$. 
Table 3. Economic parameters of spring rice as influenced by the number of seedlings hill ${ }^{-1}$ in Bardiya, Nepal, 2020

Treatments Economic parameters

\begin{tabular}{|c|c|c|c|c|}
\hline & $\begin{array}{l}\text { Production } \\
\text { cost } \\
(\mathrm{NRs} \text {. } \\
\left.{ }^{\prime} 000 \mathrm{ha}^{-1}\right)\end{array}$ & $\begin{array}{l}\text { Gross } \\
\text { return } \\
\text { (NRs. } \\
{ }^{\prime} 000 \mathrm{ha}^{-1} \text { ) }\end{array}$ & $\begin{array}{l}\text { Net } \\
\text { return } \\
(\mathrm{NRs} . \\
\left.{ }^{\circ} 000 \mathrm{ha}^{-1}\right)\end{array}$ & $\begin{array}{l}\mathrm{B}: \mathrm{C} \\
\text { ratio }\end{array}$ \\
\hline $\begin{array}{l}\text { One seedling } \\
\text { hill }^{-1}\end{array}$ & 70.84 & $157.41^{b c}$ & $86.57^{b c}$ & $2.22^{\mathrm{b}}$ \\
\hline $\begin{array}{l}\text { Two seedlings } \\
\text { hill }^{-1}\end{array}$ & 71.72 & $177.39^{\mathrm{a}}$ & $105.67^{\mathrm{a}}$ & $2.47^{\mathrm{a}}$ \\
\hline $\begin{array}{l}\text { Three } \\
\text { seedlings } \\
\text { hill }^{-1}\end{array}$ & 72.60 & $169.02^{\mathrm{ab}}$ & $96.42^{\mathrm{ab}}$ & $2.32^{\mathrm{ab}}$ \\
\hline $\begin{array}{l}\text { Four } \\
\text { seedlings } \text { hill }^{-} \\
1\end{array}$ & 73.48 & $140.33^{\mathrm{d}}$ & $66.85^{\mathrm{d}}$ & $1.91^{\mathrm{c}}$ \\
\hline $\begin{array}{l}\text { Five seedlings } \\
\text { hill }^{-1}\end{array}$ & 74.36 & $146.61^{\mathrm{cd}}$ & $72.25^{\mathrm{cd}}$ & $1.97^{\mathrm{c}}$ \\
\hline SEM ( $( \pm)$ & & 4.07 & 3.66 & 0.06 \\
\hline $\operatorname{LSD}(0.05)$ & & 15.15 & 15.15 & 0.21 \\
\hline F-test & & $* * *$ & $* * *$ & $* * *$ \\
\hline CV (\%) & & 6.22 & 11.50 & 6.23 \\
\hline Grand Mean & & 158.15 & 85.55 & 2.18 \\
\hline
\end{tabular}

Note: LSD: least significant differences, SEM $( \pm)$ : Standard error of mean, CV: Coefficient of variation, Treatment means separated by Duncan's Multiple Range Test and columns represented with the same letter(s) are not significantly different among each other at 5\% level of significance.

\section{ACKNOWLEDGEMENT}

The authors acknowledge the platform and funding availed by Prime Minister Agriculture Modernization Project, rice superzone, PIU Rajapur, Bardiya. Also, the authors thank the guidance, and supervision provided by the Faculty of Agriculture, Agriculture and Forestry University.

\section{REFERENCES}

Alam, M., Baki, M., Sultana, M., Ali, K., and Islam, M. 2012. Effect of variety, spacing and number of seedlings per hill on the yield potentials of transplant aman rice. International Journal of Agronomy and Agricultural Research, 2(12), 1015.

Ashraf, M., Khalid, A., and Ali, K. 1999. Effect of Seedling Age and Density on Growth and Yield of Rice in Saline Soil. Pakistan Journal of Biological-Sciences, 2(3):860-862. DOI: $10.3923 /$ pjbs. 1999.860 .862

Azad, A. 2004. Effect of spacing and number of number of seedlings hill ${ }^{-1}$ on yield and yield contributing characteristics of transplant aman rice cv. BR11. Mymensingh, Bangladesh: Bangladesh Agricultural University.

Barua, R., Islam, M. N., Zahan, A., Paul, S., and Shamsunnaher. 2014. Effects of spacing and number of seedlings per hill on the yield and yield components of BRRI dhan47. Eco-friendly Agriculture Journal, 7(6): 65-68.

Bhowmik, S. K., Sarkar, M. A., and Zaman, F. 2012. Effect of spacing and number of seedlings per hill on the performance of aus rice cv. NERICA 1 under dry direct-seeded rice (DDSR) system. Journal of Bangladesh Agricultural University, 10(2): $191^{-1}$ 95. DOI: 10.3329/jbau.v10i2.14681

Dejen, T. (2018). Effect of plant spacing and number of seedlings per hill to transplanted rice (Oryza Sativa X Oryza Glaberrima) under irrigation in Middle Awash, Ethiopia. Journal of Applied Life Sciences-International,17(4):1-9. DOI: 10.9734/JALSI/2018/42081

Ehsanullah, Jabran, K., Asghar, G., Hussain, M., and Rafiq, M. 2012. Effect of nitrogen fertilization and seedling density on fine rice yield in Faisalabad, Pakistan. Soil Science Society of Pakistan, 31(2):152-156.

FAOSTAT. 2019. Agriculture statistical database. Retrieved from http://faostat.fao.org

Faruk, M., Rahman, M., and Hasan, M. 2009. Effect of Seedling Age and Number of Seedling per Hill on the Yield and Yield Contributing Characters of BRRI Dhan 33. International Journal of Sustainable Crop Production, 4(1): 58-61.

Gurjar, G. N., Swami, S., and Meena, N.K. 2018. Effect of age of seedling and number of seedlings per hill on growth and yield of low land rice cultivation in Asia - A Review. International Journal of Current Microbiology and Applied Sciences, 7(6):3751-3760.

DOI: https://doi.org/10.20546/ijcmas.2018.706.4 39

Hasanuzzaman, M., Nahar, K., Roy, T., Rahman, M., Hossain, M., and Ahmed, J. 2009. Tiller Dynamics and Dry Matter Production of Transplanted Rice as Affected by Plant Spacing and Number of Seedling per Hill. Academic Journal of Plant Sciences, 2(3): 162-168.

Inaba, K., and Kitano, M. 2005. Effect of number of seedlings per hill on rice tillering. Japanese. Jour. Crop Sci, 74 (2): 141-148.

Islam, M., Akhter, M., Rahman, M., Banu, M., and Khalequzzaman, K. 2008. Effect of Nitrogen and number of seedlings per hill on the yield and yield components of T. AMAN RICE (BRRI Dhan 33). International Journal of Sustainable Crop Production, 3(3): 61-65.

Lakshmi V.M., Suneetha Y., Yugandhar G., Lakshmi V.N. 2014. Correlation studies in rice (Oryza sativa L.). International Journal of Genetic Engineering and Biotechnology, 5(2): 121-126.

Mamun, A., Sarkar, M., and Uddin, F. J. 2010. Effect of variety, number of seedling hill ${ }^{-1}$ and fertilizer application on the growth and yield of fine rice under late transplanted condition. Journal of Agroforestry and Environment., 4(2): 177-180. 
Masum, S. M., Ali, M. H., Hasanuzzaman, M., Chowdhury, I. F., Mandal, M. S., and Jerin, R. 2014. Response of variety and population density on yield attributes and yield of boro rice (Oryza sativa). Annals of Agricultural Research New Series, 35(4): 355-361.

Miah, M. N., Talukder, S., Sarkar, M. A., and Ansari, T. H. 2004. Effect of Number of Seedling per Hill and Urea Supergranules on Growth and Yield of the Rice cv. BINA Dhan4. Journal of Biological Sciences, 4: 122-129. DOI: $10.3923 /$ jbs.2004.122.129

MoALD. 2020. Statistical Information on Nepalese Agriculture 2075/76 (2019/20). Singha Durbar, Kathmandu: Government of Nepal, Ministry of Agriculture and Livestock Development, Statistics and Analysis Section.

Muthayya, S., Sugimoto, J. D., Montgomery, S., and Maberly, G. F. 2014. An overview of global rice production, supply, trade, and consumption. Annals of the New York Academy of Sciences 1324(1): 7-14. DOI: 10.1111/nyas. 12540

PMAMP. 2019. Zone Profile. Rajapur, Bardiya: Government of Nepal, Ministry of Agriculture and Livestock Development, Prime Minister Agriculture Modernization Project.
Rasool, F.u., Habib, R., and Bhat, M. 2012. Evaluation of plant spacing and seedlings per hill on rice (Oryza sativa L.) productivity under temperate conditions. Pakistan Jornal of Agricultural Sciences, 49(2): 169-172.

Rahman, M. H., Khatun, M. M., Mamun, M. A. A., Islam, M. Z., and Islam, M. R. 2007. Effect of number of seedling hill ${ }^{-1}$ and nitrogen level on growth and yield. Journal of Soil and Nature, 1(2):1-7.

Sarkar, M. A., Paul, S. K., and Hossain, M. A. 2011. Effect of row arrangement, age of tiller seedling and number of tiller seedlings per hill on performance of transplant aman rice. The Journal of Agricultural Sciences, 6(2):59-68. DOI: 10.4038/jas.v6i2.3860

Tripathi, B. P., Bhandari, H. N., and Ladha, J. K. 2019. Rice strategy for Nepal. Acta Scientifc Agriculture, 3(2): 171-180.

Yadanar S.M., Mar S.S., Than A.A. and Ngwe K. 2018. Effect of nitrogen and potassium on yield and yield components of rice. Conference: Proceedings of the eleventh Agricultural Research Conference. Yezin Agricultural University.

Citation: Paudel, H.; Dhakal, S.; Shrestha, K.; Paudel, H. and Khatiwada, D. 2021. Effect of number of seedlings per hill on performance and yield of spring rice (Oryza sativa L.) in Rajapur, Bardiya, Nepal. International Journal of Agricultural and Applied Sciences, 2(1): 61-67. https://doi.org/10.52804/ijaas2021.217

Copyright: () Paudel et.al. 2021. Creative Commons Attribution 4.0 International License. IJAAS allows unrestricted use, reproduction, and distribution of this article in any medium by providing adequate credit to the author(s) and the source of publication. 